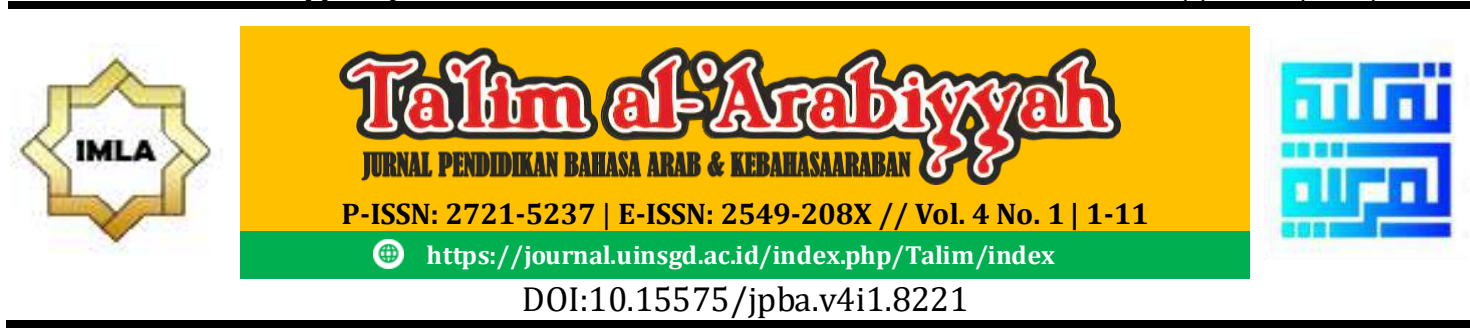

\title{
TECHNOLOGY FOR FOUR SKILLS ARABIC IN THE ERA EMERGENCY OF COVID-19 IN INDONESIA
}

\author{
Suci Ramadhanti Febriani ${ }^{1}$, Anasruddin ${ }^{2}$ \\ ${ }^{1}$ UIN Maulana Malik Ibrahim Malang, Indonesia \\ ${ }^{2}$ Institute Tahfidz Qur'an Sulaimaniyah, Turki. \\ Corresponding Email: 17721004@student.uin-malang.ac.id
}

\begin{abstract}
The integration of technology and learning has become the primary key in developing various Arabic learning models in emergencies of the COVID-19 era. This study aims to describe and uncover the impact of technology on the learning process of Arabic on four Arabic language skills. This research uses a qualitative approach design utilizing the case study research method. Data obtained through observation techniques, interviews, and documentation with data analysis techniques using the theory of Milles and Huberman. The results revealed that the impact of technology on learning Arabic included several aspects of innovation in curriculum planning, implementation of learning, strategy development, and evaluation that varied online. The findings of this study are that the integration of technology with Arabic learning can improve creative and critical thinking processes and form a constructivist mindset. This study recommends that the use of appropriate technology for four language skills will affect Arabic learning outcomes to the maximum.

Keywords: Arabic Learning, Creative Thinking, Critical Thinking, Technology.
\end{abstract}

\section{ABSTRAK}

Integrasi teknologi dan pembelajaran menjadi kunci utama dalam mengembangkan berbagai model pembelajaran bahasa Arab dalam keadaan darurat COVID 19. Penelitian ini bertujuan untuk menggambarkan dan menganalisis dampak teknologi pada proses pembelajaran bahasa Arab pada empat keterampilan berbahasa. Penelitian ini menggunakan desain pendekatan kualitatif dengan menggunakan metode penelitian studi kasus. Data diperoleh melalui teknik observasi, wawancara dan dokumentasi dengan teknik analisis data menggunakan teori Milles dan Huberman. Hasil penelitian menunjukkan bahwa dampak teknologi pada pembelajaran bahasa Arab mencakup beberapa aspek inovasi dalam perencanaan kurikulum, implementasi pembelajaran, pengembangan strategi dan evaluasi yang bervariasi secara online. Temuan penelitian ini adalah bahwa integrasi teknologi dengan pembelajaran bahasa Arab dapat meningkatkan proses berpikir kreatif dan kritis dan membentuk pola pikir konstruktivisme. Studi ini merekomendasikan bahwa penggunaan teknologi yang tepat untuk 4 keterampilan bahasa akan memengaruhi hasil belajar bahasa Arab secara maksimal.

Kata Kunci: Berfikir Kreatif, Berfikir Kritis, Pembelajaran Bahasa Arab, Teknologi. 
Ta'lim al-'Arabiyyah : Jurnal Pendidikan Bahasa Arab dan Kebahasaaraban, 4 (1), 2020

\section{INTRODUCTION}

Since the government regulation in SK BNPB No.130A 2020, which contains an appeal for all Indonesian people to work at home, study at home and have limited activities outside the home (Ayunda Pininta, 2020). This has a drastic impact on the learning process of students. Not only students but the teachers must also have additional competence to design the learning based on technology.

Several competencies such as collaboration, self-direction, systems thinking, and communication technology management are very complex to participate fully and productively in preparing for an increasingly global, technological, and information based on technology (Davis \& Fullerton, 2016). Teachers' knowledge and skills are one of the main concerns (Carver, 2016). So, the running process can undoubtedly be done with detailed planning; the maximum activity process and the results obtained can achieve the desired goals.

One of the important aspect is technology (Kiliçkaya, 2020). Technology has a positive impact on students' Arabic ability. This is indicated by the emergence of various Arabic learning media that are varied. The need to use technology is a must. The current learning process cannot be carried out except via technology which is the main media in delivering instructions for learning at home.

Language learning can be improved by using technology. One example is that technology can help students to improve English language performance and improve thinking more reflective processes (Tseng \& Yeh, 2019) as revealed that technology has become a significant factor in $21^{\text {st }}$-century learning (Prakash, Singh, \& Yadav, 2016). According to Docekal that technology can be integrated through two sides, namely, technology becomes a need for teachers to have the ability to operate it and increase the effectiveness of learning Arabic using technology (Dočekal \& Tulinská, 2015). With this statement, the technology can be used as a tool to improve students' abilities in practicing four language skills, such as listening, speaking, reading, and writing (Godwin, 2015). This skill can be trained to the maximum through exciting collaboration between various learning strategies and media. The success of foreign language learning is also supported by many factors (Wahab, 2016).

Some previous studies have found that Docekal argues that some of the effects of technology on learning are giving students the freedom (Dočekal \& Tulinská, 2015). The previous discussion underscored the importance of testing the role of technology in learning in the socio-cultural context in which learning takes place(Davis \& Fullerton, 2016). Carrier also agreed that technology can provide new and significant opportunities for foreign language students and teachers (Carrier, Damerow, \& Bailey, 2017). Lai's research revealed that helping students to become independent learners, who can actively utilize technology for learning outside the classroom, is essential for successful language learning (Lai, Yeung, \& Hu, 2016). When digital technology has become more sophisticated, tools and applications can be used inside and outside the classroom, both in formal and informal environments, this is one of the media to increase student motivation in learning languages (Panagiotidis, 2018). The use of technology also can improve students' competence and skills in listening, speaking, reading and writing skills (Hembrough \& Jordan, 2020). This increases learning opportunities that are not limited by space and time. 


\section{Ta'lim al-'Arabiyyah : Jurnal Pendidikan Bahasa Arab dan Kebahasaaraban, 4 (1), 2020}

Some effects related to the four foreign language skills can be seen such as when the practice of listening to the language being learned, technology gives students more options and is only limited by instructor knowledge about how to arrange sound pedagogical tasks to accompany technology such as videos (Blake, 2016). Students must have a clear domain of instruction from teachers about what activities they will do to improve their listening skills through technology intermediaries (Carver, 2016). Also, in the process of speaking can be helped by technology. It appears that teaching in the classroom in general, can foster interaction and help students to see their gaps in their knowledge of foreign languages, whereas if using technology, students can be facilitated for storage of memory from phonemic and morphological differences and assist in a phrase search (Blake, 2016). Kern (Kern, 2014) also revealed that he believed when the process of reading and writing on the internet involved a new type of media facilitated by technology, which of course, changed the nature of these activities slowly. For example, most students today use Wikipedia as their only source of reading, which is not a good thing when one of the goals of foreign language learning is to develop critical thinking together with a more multilingual identity.

Based on the facts above, it is known that Indonesia experiences rapid growth and development on the impact of technology used by the teachers and students in Arabic learning. On that basis, researchers want to describe and analyze how the effect of technology on the four Arabic language skills in Indonesia.

\section{METHOD}

This research uses a qualitative approach model with a case study research method data collected from observations, interviews, field studies and documentation (Musthafa \& Hermawan, 2018). Through observation, interviews and field studies, representations can be made about the impact of technology on foreign language skills. Various forms of secondary data are used to supplement primary data, such as written sources of articles and teaching plans. Informants in this study were Arabic language teachers at Al-Azhar Padang Elementary School, Tangerang Syafana Islamic School, Al-Kautsar Elementary School in Malang and Islamic Elementary School in Padang.

Researchers conduct research related to learning Arabic online. After that, researchers interviewed Arabic teachers in four elementary schools as a sample of how the impact of the use of technology on improving Arabic language skills. Then the researcher follows and observes the learning process that is done online and checks the completeness of the documents used by the teacher as material for planning, implementing, and evaluating learning. The data collected was then analyzed using data analysis techniques used based on Milles and Hubbermans' theory. The data was collected and described, then reduced and verified in detail. During the data collection phase, researchers noted the Arabic learning process that was carried out online and the direct impact felt by the teacher or students. After collecting data, researchers then reduce the data by selecting and sorting data that supports search. Then, verify at this point that the researcher has determined the primary data as essential data, and sorted out the unwanted data. The design of this study can be seen in the following chart. 
Figure 1. Methodology of Research

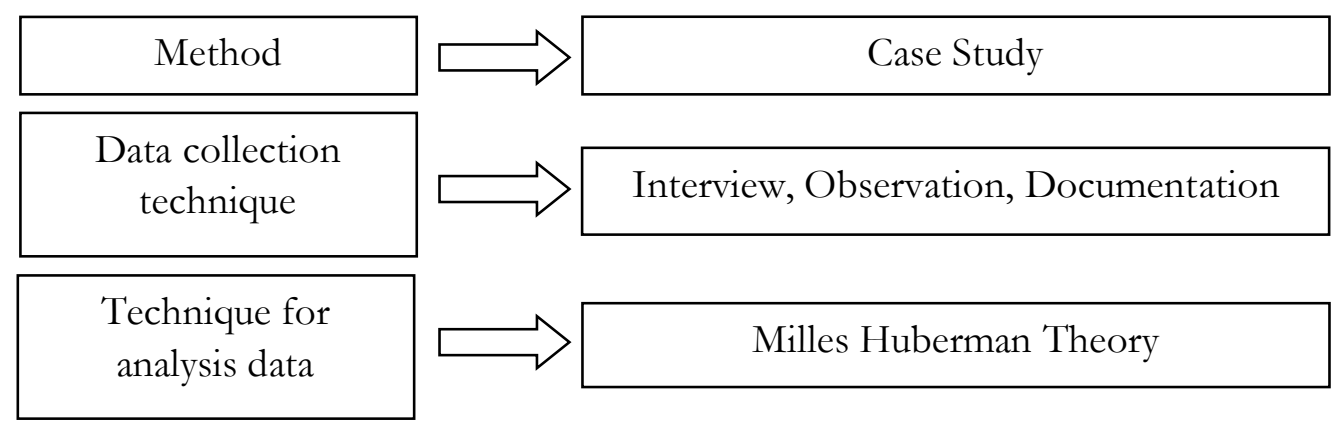

\section{RESULT AND DISCUSSION}

Globalization is one of the essential factors in changing the language education system (Tribak Oifaa, 2019). The development of technology in the world of education has resulted in a distance learning system. With this system, a student no longer needs to go to school like a formal school, and this has happened when the emergence of the COVID-19 epidemic. But students simply take the time to meet face to face with the teacher through a computer monitor or mobile. Likewise, students cannot obtain information about knowledge through online references to acquire knowledge that is already available on an online basis. Even a teacher will quickly search for teaching materials that are appropriate to his field. Also, a student can explore the knowledge gained by being supported by the ability to search for additional information beyond that taught by the teacher.

Learning Arabic in Indonesia has goals that have been set by the government starting from elementary, secondary, and tertiary levels in Minister of Religion Decree No. 183 and 184 (Madrasah, Jenderal, Islam, Agama, \& Indonesia, 2019). Some instruments that need to be emphasized are the use of technology as a learning medium on all sides. In times of disaster emergency like now, the world always requires technology to facilitate daily activities. The learning process that is applied is also based online. Various impacts caused by technology cannot be denied to be positive things towards learning Arabic.

Technological innovations break the boundaries in learning Arabic, either from making independent learning more efficient, adding value to the time spent in class or by giving broader exposure to language education so that more students can access it. By bringing overall services closer to the place and time of demand, technology plays an essential role in supporting learning success.

Some of the impacts that occur when technology becomes the subject of discussion among teachers and students on foreign language learning skills are very heterogeneous. The following is a more detailed explanation of the impact that technology has had on four Arabic language skills. 


\section{Technology and Listening Skills}

Traditional learning that is usually done in the classroom justifies students' boredom in learning Arabic, and this is characterized by minimal student response when learning by using a teacher-centered learning system (Wahyudin, 2020). Monotonous and non-varied learning processes cause teaching goals to be suboptimal. The use of technology can be an effort to improve students' abilities.

In practice, the use of technology has a positive impact on students' listening abilities. The teacher said that students have the right motivation and interest when given learning instructions through online-based media. Some of the media used to train students' online listening skills is through applications that have been used by teachers, namely Youtube, WhatsApp record, Zoom. Students can listen to simple stories through teacher-developed media or videos that have been designed. At that time, students can distinguish pure sounds through video props. Then students can choose and classify the sounds and vocabulary learned with virtual media. With technology, students can practice sensitivity to sound, vocabulary that is played. Because when the learning process takes place, students must first understand the instructions given by the teacher. For example, in the assessment process, students can listen and distinguish sounds, vocabulary through recordings provided by the teacher.

Through recordings or videos that are played, students can study simple conversations then comment on the activities carried out in the video being played. However, it is still in criticism of the vocabulary presented. The technology significantly impacts the increasing critical power and creativity of students. Usually, learning in the classroom will form a narrower paradigm than learning based on selfawareness.

When the process of learning to listen to using technology media, students demonstrate the ability to distinguish and understand vocabulary quickly. Some factors that support students' responses are unusual intonation of voice and different conversations in different sessions, so that encouragement is better than learning in class. Several technology options can be used to stimulate students in practicing critical thinking.

Some facts found that there are some constraints when listening, unclear teacher instructions and interactions that are still less effective online require students to understand the discourse that is well attended to, not to mention the constrained network and the lack of student activity when online learning is felt to be one of the obstacles.

\section{Technology and Speaking Skills}

Speaking skills can be helped with technology. Some tutorials and instructions must be clear when technology provides options to enhance positive interactions in using Arabic (Hermawan, 2018). When studying in class, students still have anxiety and worry about speaking in class. But when teachers use technology applications, students compete in uploading their learning outcomes. Based on facts like that, technology can help students' creative thinking processes. For example, when the teacher gives instructions to have a conversation to introduce themselves, then students innovate how to present themselves using Arabic properly. 
Besides, technology can help teachers to distinguish students' speaking abilities quickly and in detail. When students send assignments to upload their conversations in the allotted time, the teacher gets results speedily and maps out how students' abilities in terms of skills and knowledge in using language elements.

Today's language learners also enjoy being video producers because, at their fingertips, there are various digital video tools, which they routinely use to upload recordings to YouTube. Through technology intermediaries, students get positive responses from several people who help justify their mistakes in speaking. For example, when students upload their conversion process to the Youtube application, some people comment on their mistakes, starting with pronunciation or vocabulary. This activity also helps the teacher in correcting each student in learning speaking skills.

Some facts show a negative impact on the use of technology when learning speaking skills. Students don't get maximum attention from the teacher. This is because of limited instructions and time to correct one by one each student's response. The need for emphasis and speaking exercises to be one of the main elements that affect the results of students' speaking skills, even though they are already using technology.

\section{Technology and Reading Skills}

Technology provides broad options for articles that are interesting to read. At the Elementary School level, teachers still design simple learning materials through power points and share them with students through the WhatsApp application. After the instruction is given, the teacher gives the assignment and is sent via the Email or WhatsApp application. Some teachers also provide vocabulary games after students read simple paragraphs related to the material.

Through technology, teachers can evaluate students' reading skills quickly. Through the process of reading through technology intermediaries, students feel different variations. They can choose several websites related to learning themes, then students classify unknown vocabulary and search for answers through google translation, or ask questions directly with the teacher. After students are given assignments to read according to proper pronunciation, students send tasks and upload them in online applications, such as Instagram and to the teacher.

Some of the activities above can improve students' critical thinking processes when they choose articles following the material provided by the teacher. The reading material used as a reference is also illustrated and gives positive responses to students in the form of increased motivation in reading Arabic. In addition to positive effects, using technology in learning reading skills has a negative impact when students use Google translate as a whole to interpret Arabic text. The need for individual supervision and suitable strategies to encourage students can bring and understand Arabic texts well independently.

\section{Technology and Writing Skills}

Writing skills are the latest skills in foreign language competence. One impact resulting from the use of technology is to make it easier for students to provide responses or assignments to teachers. Usually, the teacher gives an appointment and is 
given to the teacher. For example, students write in books with instructions that have been given. Then students send in interesting photo shapes or design drawings. With the help of technology, students can look for different and creative innovations. This can help critical thinking when designing simple writing. Some important points of concern when the learning of writing skills process needs a good strategy and suitable media to allow students to be creative in writing. However, the suitability of the media is one of the influences on the effectiveness of learning to write.

The real impact of technology on language skills is that students can collaborate on the $4 \mathrm{c}$ abilities needed in this era. According to Carol, the contextual learning process can develop critical power and one of the significant investments in foreign language learning (Griffiths \& Oxford, 2014). The limited-time when the Corona outbreak did not dampen creativity, cooperation, excellent communication and critical thinking among elementary school students. Some of these elements appear when the process of learning Arabic is based online. The following are the results of the learning stages obtained through information technology applied by teachers in Arabic learning.

Figure 2. Students and Teacher Projects

\begin{tabular}{|c|}
\hline $\begin{array}{c}\text { Management of teaching materials based } \\
\text { on technology }\end{array}$ \\
\hline Design of language learning by the teacher \\
\hline Online-based learning process \\
Creativity \\
Collaborative \\
Communication \\
\hline
\end{tabular}

Technology-supported language learning will shape some of the skills in the $21^{\text {st }}$ century. Some things can be seen clearly when students can learn Arabic independently. They can classify foreign language vocabularies through four integrated skills. Through the recording or instruction given by the teacher, students can group vocabulary that is not yet known, then search for meaning independently, and design simple conversations through the vocabulary that has been explained, after which they unconsciously write communications created to practice writing skills. 
Based on the stages of Arabic language learning integrated with four language skills, students can create independent learning by the constructivist approach (Huang, 2018). Unconsciously, students can give meaning to language learning, which is very effective against the four skills taught by the teacher as it is known that constructivism learning can provide excellent opportunities for students to improve critical thinking skills (Rusdin, 2018).

Bloom's theory (Teimourtash \& YazdaniMoghaddam, 2017) that the level of critical thinking starts from the stages of understanding, analyzing, applying, evaluating, creating. Recent research facts that the low ability of students to think critically, communicate and collaborate causes learning output not following the demands of the times (Marlina, 2019).

The impact of technology can help the student's revolving stage as follows.

Figure 2. Learning Steps based on Technology

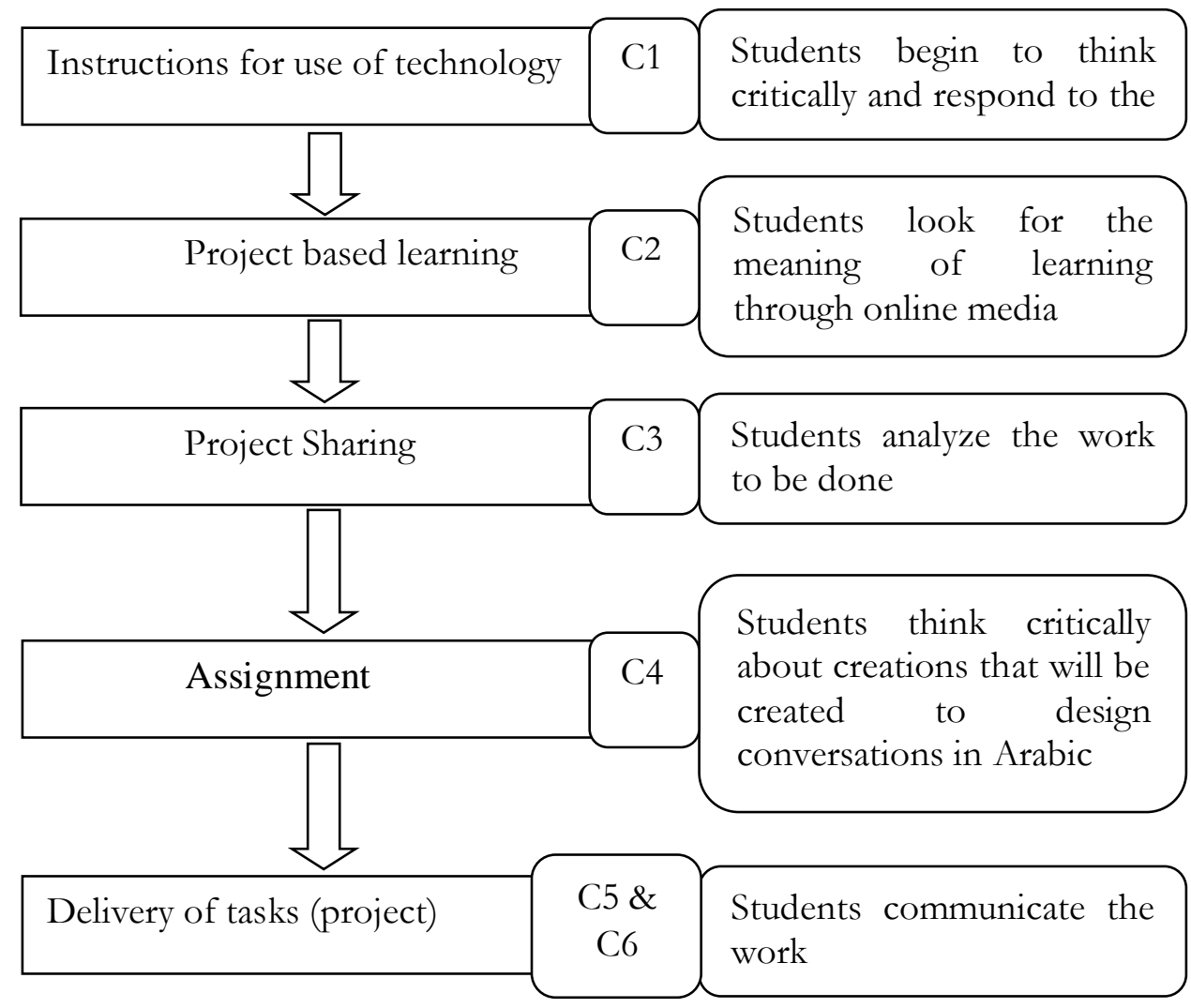

Through the picture, language learning can provide opportunities for students to obtain integrative learning in learning four Arabic language skills. As the demands of $21^{\text {st- }}$ century skills significantly affect all aspects of life, especially education. To prepare students for the challenges of the $21^{\text {st }}$ century, namely to become lifelong learners, educators in Indonesia must apply different lessons that are tailored to the goals set by the government (Freeman, Ed, \& Ave, 2016). 
The following challenges are faced in implementing critical thinking processes in language learning classes. According to Portelli (Portelli, 1994), teacher ideology needs to be changed because the majority still believes that traditional learning models are still active, and teacher-centered learning needs to be changed to student-centered learning because it cannot encourage students' critical thinking processes. United Nations demands also help the government of Indonesia to develop problem-based learning (Musa, Mufti, Latiff, \& Amin, 2012)

\section{CONCLUSION}

The various technology can motivate Arabic learners from elementary to tertiary levels during emergencies (COVID-19). Multiple effects of technology on the four language skills are very gradual, starting from the process of classifying letters and words, then talking about the vocabulary learned until finding the meaning of words and writing words in assignments. The results of this study indicate that four skills can be improved by using technology. In addition to integrated material, strategies, media, and adequate evaluation, students can learn Arabic. The various assignments can build a process of critical thinking, creative thinking, and students can learn independently in a broader context. This study found that the impact of technology on students' language skills is when the constructivist approach can provide many opportunities and opportunities for students to be creative through the four Arabic language skills. The implications of this study offer operational ideas to policymakers to plan, implement and evaluate Arabic learning based on technology so that four Arabic language skills students can be trained in a gradual and integrated language learning process. This study recommends further research to determine the effectiveness of using technology in every Arabic language skill in Indonesia.

\section{REFERENCES}

Ayunda Pininta. (2020, March). Bila Belajar di rumah diperpanjang: Tak harus Online dan Akademis. Kompas, p. 1.

Blake, R. (2016). Technology and the four skills. Language Learning and Technology, 20(2), 129-142.

Carrier, M., Damerow, R. M., \& Bailey, K. M. (2017). Digital language learning and teaching: Research, theory, and practice. Digital Language Learning and Teaching: Research, Theory, and Practice, 22(1), 1-264. https:// doi.org/10.4324/9781315523293

Carver, L. B. (2016). Teacher perception of barriers and benefits in K-12 technology usage. Turkish Online Journal of Educational Technology, 15(1), 110-116. https://doi.org/10.21125/inted.2016.1845

Davis, K., \& Fullerton, S. (2016). Connected learning in and after school: Exploring technology's role in the learning experiences of diverse high school students.

Information Society, 32(2), 98-116. https://doi.org/10.1080/01972243.2016.1130498

Dočekal, V., \& Tulinská, H. (2015). The Impact of Technology on Education Theory. 
Ta'lim al-'Ara6iyyah : Jurnal Pendidikan Bahasa Arab dan Kebahasaaraban, 4 (1), 2020

Procedia - Social and Behavioral Sciences, 174, 3765-3771.

https://doi.org/10.1016/j.sbspro.2015.01.1111

Freeman, I. M., Ed, D., \& Ave, E. A. (2016). Life Skills for 21 st Century Learners. 3(10), 49-52.

Godwin, R. (2015). Emerging Technologies Contributing, Creating, Curating: Digital Literacies for Language Learners. Language Learning \& Technology, 19(193), 8-20.

Griffiths, C., \& Oxford, R. L. (2014). The twenty-first century landscape of language learning strategies: Introduction to this special issue. System, 43(1), 1-10.

https://doi.org/10.1016/j.system.2013.12.009

Hembrough, T., \& Jordan, J. (2020). Creating a digital writing classroom: A mixed methods study about a first-year composition tablet initiative. International Journal of Instruction, 13(2), 567-586. https://doi.org/10.29333/iji.2020.13239a

Hermawan, A. (2018). Pembelajaran Keterampilan Berbahasa Arab Dengan Pendekatan Komunikatif-Interaktif. Bandung: PT Remaja Rosakarya.

Huang, S. C. (2018). Language learning strategies in context. Language Learning Journal, 46(5), 647-659. https://doi.org/10.1080/09571736.2016.1186723

Kern, R. (2014). Technology as Pharmakon: The promise and perils of the internet for foreign language education. Modern Language Journal, 98(1), 340-357. https://doi.org/10.1111/j.1540-4781.2014.12065.x

Kılıçkaya, F. (2020). Learners' perceptions of collaborative digital graphic writing based on semantic mapping. Computer Assisted Language Learning, 33(1-2), 58-84. https://doi.org/10.1080/09588221.2018.1544912

Lai, C., Yeung, Y., \& Hu, J. (2016). University student and teacher perceptions of teacher roles in promoting autonomous language learning with technology outside the classroom. Computer Assisted Language Learning, 29(4), 703-723. https://doi.org/10.1080/09588221.2015.1016441

Madrasah, D. K., Jenderal, D., Islam, P., Agama, K., \& Indonesia, R. (2019). Keputusan Menteri Agama Tentang.

Marlina, D. (2019). Analisis Kemampuan Literasi Sains Pada Mahasiswa. 4(1), 9-18.

Musa, F., Mufti, N., Latiff, R. A., \& Amin, M. M. (2012). Project-based Learning (PjBL): Inculcating Soft Skills in 21st Century Workplace. Procedia-Social and Behavioral Sciences, 59(2006), 565-573. https://doi.org/10.1016/j.sbspro.2012.09.315

Musthafa, I., \& Hermawan, A. (2018). Metodologi Penelitian Bahasa Arab (Konsep Dasar, Strategi, Metode, Teknik). Bandung: PT Remaja Rosakarya.

Panagiotidis, P. (2018). Technology as a Motivational Factor in Foreign Language Learning. European Journal of Education, 1(3), 43. 
Ta'lim al-'Arabiyyah : Jurnal Pendidikan Bahasa Arab dan Kebahasaaraban, 4 (1), 2020

https://doi.org/10.26417/ejed.v1i3.p43-52

Portelli, J. P. (1994). The challenge for teaching for critical thinking. McGill Journal of Education, 29(2), 137-152.

Prakash, S., Singh, A., \& Yadav, S. K. (2016). Personality (Introvert, And Extrovert) and Professional Commitment Effect among B . Ed Teacher Educator Students. The International Journal of Indian Psychology, 3(2).

Rusdin, N. M. (2018). Teachers' Readiness in Implementing 21st Century Learning. International Journal of Academic Research in Business and Social Sciences, 8(4), 12931306. https://doi.org/10.6007/ijarbss/v8-i4/4270

Teimourtash, M., \& YazdaniMoghaddam, M. (2017). On the Plausibility of Bloom's Higher Order Thinking Strategies on Learner Autonomy: The Paradigm Shift. Asian-Pacific Journal of Second and Foreign Language Education, 2(1). https://doi.org/10.1186/s40862-017-0037-8

Tribak Oifaa. (2019). The Development of English Language Teaching in Morocco: From Traditional Methods to New approaches. Applied Languange and Linguistic, 3(2), 145-160.

Tseng, S. S., \& Yeh, H. C. (2019). The impact of video and written feedback on student preferences of English speaking practice. Language Learning and Technology, 23(2), 145-158.

Wahab, M. A. (2016). Standarisasi Kurikulum Pendidikan Bahasa Arab Di Perguruan Tinggi Islam Negeri. Arabiyât, 3(1), 32-51.

Wahyudin, D. (2020). Metodologi Pembelajaran Bahasa Arab Berdasarkan Teori Unit dan Parsial. Bandung: Remaja Rosda Karya. 